\title{
The Impact of Perceived Psychological Contract Breach, Abusive Supervision, and Silence on Employee Well-being
}

\author{
Jan Morsch \\ Nyenrode Business University \\ Dana van Dijk \\ Nyenrode Business University \\ Bas Kodden \\ Nyenrode Business University
}

\begin{abstract}
The aim of this study was to examine the relationship between psychological contract breach as it is perceived by employees, the comprehensiveness of silence and the moderating effect that abusive supervision has on the relationship between psychological contract breach, silence, and indirectly on employee well-being. This study revealed support for the negative relationship between psychological contract breach and employee well-being. Quiescent silence was found to mediate the negative relationship between psychological contract breach and employee well-being. Abusive supervision was found to be a strengthening moderator in the negative relation between psychological contract breach and quiescent silence.
\end{abstract}

Keywords: psychological contract breach, work motivation, employee well-being, silence, abusive supervision

\section{INTRODUCTION}

An organization's goal is to perform efficiently, increase profits and provide adequate services. Employees are to some extend responsible for achieving these organizational objectives (Ahmad \& Khan, 2015). When employees are unsatisfied with their job performance, they become less motivated to ensure the organizational goals are being met (Adebayo \& Ogunsina, 2011). In addition, employees who are dedicated and satisfied become more punctual, committed and increase their job performance (Kodden, 2014; Kodden \& van Ingen, 2019). Employee satisfaction is therefore, not surprisingly, connected to the level of psychological well-being of employees, their organizational commitment and job performance (Ahmad \& Khan, 2015; Kodden \& Roelofs, 2019). Employee well-being can be explained by the concept of 'happiness', regarding well-being as a subjective observation, and by the concept of 'realizing human potential' regarding personal achievements (Ryan \& Deci, 2001; Zheng, Zhu, Zhao, \& Zhang, 2015). Employees with an empowered position in an organization have a distinct impact on the business environment and culture, including on employees' behavior (Johnson \& Klee, 2007). According to 
Blomme and Kodden $(2014,2015)$, leadership styles in an organization can have a positive or negative effect on the behavior of employees. Employee relations have been a main strength behind an organization's ability to compete in today's global market. Continuing to ensure relations with various stakeholders of the organization is essential for any organizational performance (Armstrong, 2006). Lifetime commitment towards an organization used to be considered normal by employees, but nowadays, changing careers is an accepted practice (Weng \& McElroy, 2010). The modern dynamic and people-focused nature of an organizational environment brings along challenges. A main challenge is to secure the satisfaction of employees, ensuring their commitment towards the company. Savickas (2011) states that ownership of one's career has changed significantly through the years. Nowadays, an individual's career is his or her own to direct. The decision to leave an organization is still not something to think lightly of. The most common reason for employees to quit their job is because employees do not align with their superior or because they are not assured of personal or professional growth (Kodden \& Hupkes, 2019). The foundation of the relationship between an employee and an organization is set by a psychological contract (Kodden \& Roelofs, 2019; Robinson \& Wolfe Morrison, 2000). A psychological contract refers to the corresponding perceived agreements made between the organization and the employee (Rousseau, 1989). The contract is a form of social correspondence and represents mutual exchanges between employees and their organization (Suazo, Martínez, \& Sandoval, 2009; Wang \& Hsieh, 2014). Although not recognized as an official contract, the psychological contract's foundation is built on the employee's trust in the fulfillment of these agreements by the organization. A psychological contract breach is experienced whenever a party has failed to fulfill the promised agreements (Robinson \& Wolfe Morrison, 2000). According to Topa Cantisano, Morales Dominquez, and Depolo (2008), a psychological contract breach is seen as more than just not living up to expectations. A psychological contract breach's influence extends to the foundational beliefs of the employee with regards to respect and trust in his or her manager and organization. It therefore has been said that psychological contract breach negatively relates to the work performance of employees (Kodden \& Roelofs, 2019; Bal, Chiaburu, \& Jansen, 2010).

\section{THEORY AND HYPOTHESES}

\section{Employee Well-being in Relation to Psychological Contract Breach}

According to Danna and Griffin (1999), research has shown that employee well-being has a significant impact on the longevity of organizations within the market and is the key to organizational productivity and success (Kodden \& van Ingen, 2019). Leaders and managers spend extensive organizational resources to increase the well-being of their employees in numerous ways (Hartwell et al., 1996). Based on the social exchange theory of Blau (1964), employees who perceive a psychological contract being breached will experience a negative effect as a result of such a breach on their behavior and attitude at work. Such an effect can include a decrease in job satisfaction and a decrease in commitment to responsibilities (Bal et al., 2010; Zhao, Wayne, Glibkowski, \& Bravo, 2007). When a psychological contract breach occurs, employees no longer experience the same degree of control over their economic and social stability within the organization (Reimann \& Guzy, 2016). Previous research has shown that when obligations are not met by an employer, feelings of uncertainty and lack of control increase among employees (Chambel \& Oliveira-Cruz, 2010). Siegrist (1996) established the effortreward imbalance model, which explains why psychological contract breach causes an imbalance of the relationship between employer and employee. This particular theory explains that, like the social exchange theory of Blau (1964), relationships are based on reciprocity of efforts committed to by the employee. Such efforts performed by the employee will be compensated through appropriate rewards, such as job security, salary or promotion. According to Reimann and Guzy (2016), psychological contract breach is a perceived imbalance in the working relationship between the employer and its employee. This transactional-based psychological contract breach affects employees' health by putting employees in uncertain work situations that can cause stress and imbalance between the idea of committing effort to retrieve a desired reward. Based on these findings, the following hypothesis is drafted: 
Hypothesis 1: A perceived transactional-based psychological contract breach is negatively associated with employees' psychological well-being.

Relational-based contracts, which are more open-ended, are often formed with the idea of long-term employment and are based on the mutual trust between employers and employees (Patrick, 2008). When a psychological contract breach takes place, employees are likely to doubt their relationship with their employer, as uncertainty arises when obligations are not being met (Reimann \& Guzy, 2016). The predictability and control employees thought to have over their work environment with regards to trust and social stability decreases, which results in negative consequences for employees' psychological health. Robbinson, Ford, and Terick (2012) mention that a psychological contract breach often goes handin-hand with the feeling of mistreatment and unfairness within the employment relationship. Additionally, these emotions can activate psychological stress among employees and eventually affect the relationship between employers and employees even further (Reimann \& Guzy, 2016). Reimann and Guzy (2016) further explain that psychological contract breaches are associates with decreases in the psychological well-being of employees. It was found that the idea of 'broken promises' is associated with consequences for employees' psychological well-being, such as burnouts, anger, depression and the feeling of being betrayed (Buunk \& Schaufeli, 1999; Conway \& Briner, 2005; Schaufeli \& Enzmann, 1998). Based on these findings, the following hypothesis is drafted:

Hypothesis 2: A perceived relational-based psychological contract breach is negatively associated with employees' psychological well-being.

\section{The Relation Between Employee Well-being, Psychological Contract Breach and Silence}

A psychological contract is a form of social exchange between employees and their organization (Wang \& Hsieh, 2014). Employees can experience a feeling of violation, which is also called a psychological contract violation (Morrison \& Robinson, 1997; Robinson \& Wolfe Morrison, 2000). Such violations often result in negative behavior of the employee, such as decreased job commitment and job satisfaction, and it can even result in workplace deviance (Wang \& Hsieh, 2014). Additionally, these consequences may prove to be harmful for employees as well as the organization (Zhao et al., 2007). A consequence of a psychological contract breach could be silence, and in particular acquiescent silence. Quiescent silence refers to a form of silence where individuals deliberately withhold useful information to protect themselves, as speaking up would result in a negative experience. This form of silence is based on feeling fearful and can also be regarded as defensive silence (Van Dyne, Ang, \& Botero, 2003). Acquiescent silence is mostly focused on the emotion of being hopeless, which is reflected in submissive behavior. Acquiescent silence focuses on the deliberate action of withholding information, ideas or opinions from the organization due to the feeling of relinquishment of responsibility (Van Dyne et al., 2003). In comparison to other behavioral consequences of psychological contract breach, acquiescent silence is a more passive and low risk undertaking for employees and is hard to detect by others in the organization. In case of quiescent silence, someone deliberately chooses to protect oneself from negative consequences (Knoll \& van Dick, 2013). Jain (2015) and Brinsfield (2009) explain that quiescent silence is chosen as a behavior to avoid the negative consequences employees' encounters when they would speak up. Based on these findings, the following hypothesis is drafted:

Hypothesis 3: A perceived psychological contract breach is positively related to employees' choice of quiescent silence.

Pro-social silence, on the other hand, can be seen as intentional and pro-active behavior, which is mainly built on reasoning regarding others (Korsgaard, Meglino, \& Lester, 1997). Engaging in pro-social silence may be due to attempting to gain social capital or protecting one's social status and relationship with the organization (Knoll \& van Dick, 2013). Pro-social silence is more focused on becoming silent to 
avoid damaging personal relations and to remain trustworthy in the eyes of their supervisor (Knoll \& Van Dick, 2013.

Hypothesis 4: A perceived psychological contract breach is positively related to employees' choice of pro-social silence.

With regards to employee well-being, silence can have many different effects (Beheshtifar, Borhani, \& Moghadam, 2012). Employees whose 'silence' is not recognized, often turn indifferent, which can slowly affect their psychological well-being through experiencing stress, depression, and this can even affect their physical health (Bagheri, Zarei, \& Aeen, 2012). Van Dyne et al. (2003) suggests pro-social form of silence entails deliberately withholding information or opinions from employers to benefit others or the organization. Remaining silent can result in employee behavior that is less accessible for coworkers (Knoll \& van Dick, 2013). Moreover, Cortina and Magley (2003) found that those employees who deliberately choose to remain silent and choose not to speak up, experience more psychological harm than when they would have chosen to speak up. Employees experience silence as uncomfortable and often feel something should be said, though they still choose not to say anything (Knoll \& van Dick, 2013). As employees' views on their circumstances affect their decision on whether or not to remain silent, their feelings will continually be affected by the thought that something should be said, and something might have to be said (Pinder \& Harlos, 2001). Based on these findings, the following hypothesis is drafted:

Hypothesis 5: Quiescent silence and pro-social silence are negatively associated with employees' psychological well-being.

\section{Moderating Effect of Abusive Supervision on the Relation Between Psychological Contract Breach and Silence}

Abusive supervision is identified as a subjective assessment of subordinates being treated offensively and being insulted (Wei \& Si, 2013), and as a display of verbal and non-verbal behavior of supervisors, excluding any physical contact (Tepper, 2000). Research has shown that organizational injustice evokes the behavior of abusive supervision (Tepper, Duffy, Henle, \& Lambert, 2006), and that supervisors who experience injustice are more likely to become more abusive to their own subordinates (Aryee, Chen, Sun, \& Debrah, 2007). Psychological contract breach implies a failure to fulfil a promise or obligation (Robinson \& Rousseau, 1994). When subordinates experience a breach of their psychological contract, a negative response can occur, such as reduced commitment, loyalty and overall happiness in their work situation (Wei \& Si, 2013). According to Xu, Loi, and Lam (2015), it often occurs that subordinates choose not to report the experience of abusive supervision due to the fact that their future in the company depends on the relation they have with their supervisor. Correspondingly, Tepper (2000) suggested that abusive supervision has an extensive effect on the attitude and behavior of employees. Employees who eventually report being a victim of abusive supervision were more likely to experience negative consequences such as job dissatisfaction within a short period of time (Qian, Song, \& Wang, 2017). Abid and Abid (2017) expand on the importance of sufficient supervisory leadership and the vital role this plays regarding the behavior of subordinates. Employees frequently examine the behavior and fairness of their supervisor, which leads to an increase or decrease in organizational commitment, job satisfaction and emotional health. Multiple studies have investigated the experience of abusive supervision and its negative effect on employee attitudes, psychological distress and even on physical well-being (Aryee et al., 2007; Ashfort, 1997; Tepper, 2000; Tepper, Moss, Lockhart, \& Carr, 2007; Tepper et al., 2007; ; Wei $\& \mathrm{Si}, 2013)$. The studies suggest that a psychological contract breach based on perceived abusiveness by supervisors can result in negative behavior of the employee, such as silence, which in return will have significant consequences for the prosperity of the organization (Abid \& Abid, 2017). Hence, transactional-based psychological contract breach is assumed to be negatively related to silence, although abusive supervision weakens this negative relationship. Abusive supervision increases employees' willingness to remain silent due to preventing shame and due to committing to self-protective behavior to 
ensure their future. Based on these findings, abusive supervision as a moderator undermines the relationship between the transactional psychological contract breach and silence. Based on these arguments, the following hypothesis was drafted:

Hypothesis 6: Abusive supervision moderates the relationship between a perceived psychological contract breach and employees' choice of committing to quiescent silence and pro-social silence.

\section{METHOD}

\section{Sample and Procedure}

Our sample consisted of 259 respondents. The response rate was $66 \%$. The data have been collected using an online questionnaire, distributed via mail, containing an anonymous link, and by means of convenience and snowball sampling. In the instructions to the survey the purpose of the research was explained and anonymity and confidentiality of the data were emphasized. 96 respondents (37.1\%) were male and $163(62.9 \%)$ were female respondents. The average age of the respondents was 39.9 years, ranging from 16 years old to 84 years old, with a standard deviation of 14.7 years. All the respondents were required to have work experience in order to fill out the survey. With regards to the organizational tenure, measured in years of working experience, the average was 10 years ranging from less than 1 year to 73 years, with a standard deviation of 11.5.

\section{Measures}

Psychological Contract Breach

In order to measure psychological contract breach, a validated questionnaire created by Bingham (2005) was used. This particular questionnaire is based on the Psychological Contract Inventory (PCI (Rousseau, 2000)), which represents the different forms of a psychological contract. These forms entail the subjective obligations set between the employer and employee (Bingham, 2005). As mentioned earlier in the theoretical framework, the different psychological contract forms include transactional-based, relational-based and ideological-based contracts.

\section{Psychological Well-being of Employees}

To measure psychological well-being of employees, the eight-item scale index of psychological wellbeing developed by Berkman (1971a, 1971b) was used. This particular scale uses similar items as Bradburn and Caplovitz's (1965) scale used in earlier research (Wright \& Cropanzano, 2000). In Berkman's (1971b) validation of the scale, the included items were based on two perspectives: a positive perspective with three items and a negative perspective with four items, to obtain an overall score representing well-being (Berkman, 1971b). In the questionnaire, items were included such as: "Do you feel depressed or very unhappy?" (Berkman, 1971b, p. 105), focusing on the negative emotions. With regards to more positive feelings, items like "Do you feel pleased about having accomplished something?" (Berkman, 1971b, p. 106) were also included. This index of psychological well-being has been validated through reproduction of the analyses regarding stress-factors by Langner and Michael (1963).

\section{Silence}

Silence was measured by using the questionnaire developed by Knoll, and van Dick (2013). This questionnaire consisted of a scale of 16 items to measure silence, which included three items to measure quiescent silence and three items to measure pro-social silence. Only these two forms of silence were used, as the motivation behind these forms is based on fear and negative consequences on one's career (Knoll \& van Dick, 2013). An example of one of the three items regarding quiescent silence, is: "because of fear of negative consequences" (Knoll \& van Dick, 2013, p. 7) and an example of an item to measure pro-social silence, is: "because I do not want to hurt the feelings of colleagues or superiors" (Knoll \& van Dick, 2013, p. 7). 


\section{Abusive Supervision}

In order to measure abusive supervision, the measurement scale regarding abusive supervision of Tepper (2000) was used. The scale measures abusive supervision by concentrating on a supervisor's abusive behavior towards their subordinates. This version consists of 15 -items and has been scored using a five-point Likert-scale, ranging from "I cannot remember him/her ever using this behavior with me" (1) to "He/she used this behavior very often with me" (5). For this thesis, Tepper's (2000) original measurement was used to capture the perceptions of abuse targeted at oneself. In the questionnaire, example items are: "My supervisor puts me down in front of others" (Tepper, 2000, p. 189) or "My supervisor expresses anger at me when he/she is mad for another reason" (Tepper, 2000, p. 190). The construct of 'abusive supervision', with a total of fifteen items within the scales, has a Cronbach's alpha score of .95 , which reflects the excellence of the internal consistency of the construct.

\section{Control Variables}

This study included control variables. Previous research has shown that gender often has a significant influence on the outcome variables, as males and females react differently (Goodrich, 2014; Pinder \& Harlos, 2001. With regard to silence, women and men express themselves differently in similar contexts (Pinder \& Harlos, 2001). Women are more likely to use a version of silence with a more supportive perspective compared to men who often use silence as a countermeasure of expressing themselves. In relation to a perceived psychological contract breach, males' and females' affiliation towards the organization is often different, which can affect the perception of fulfillment of obligations of the organization (Heilman \& Chen, 2005). Males are often more focused on their own achievements and competiveness in the work environment. Females, on the other hand, are often engaging themselves in the social structure of the organization and have a more nurturing nature. The choice of remaining silent can therefore depend on gender (Bingham, 2005). Moreover, perceptions of leadership qualities differ among males and females (Neubert \& Taggar, 2004). Such perceptions can affect the interpretations given by employees to supervisors' abusiveness. For these reasons, the control variable 'gender' has been incorporated in this study. Age has also been included as a control variable in this study. It has been found that age influences the way and the extent of how people react in different situations, and in particular the reactions towards psychological contract breach (Bal et al., 2010). Additionally, Bal, De Cooman, and Mol (2013) found that age is, to a certain degree, related to the transactional-based and the relationalbased forms of contract breach. Older individuals have more experience in social and work environments (Steverink \& Lindenberg, 2006). Therefore, age was included as a control variable in this study and was measured via a horizontal slide option. The final included control variable was organizational tenure. This variable resembles the impact of age, as work experience increases over the years. According to Boliotur and Turnley (2003), employees' perceptions and behavior is based on differential sort of experiences gained through years of working in business environments. Furthermore, Robinson (1996) suggests that organizational tenure is related to the relation-building process between employees and employers, as over years of working together in the same environment, possible psychological contract breaches are more likely to have occurred. Moreover, over the years, employees acquire more experience in the same working environment and have more time to invest in the relationship with their supervisor. So, such employees have a more stable mindset and are less likely to become overly emotional as a response to experiences which have the potential to lead to perceptions of unfulfilled obligations (Bal et al., 2013). As a result, 'organizational tenure' is incorporated in this study as a control variable.

\section{Data Analysis}

The data were analyzed with Pearson correlations and regression analyses in SPSS version 25. Mediation analyses were performed using PROCESS v3.1 for SPSS. 


\section{RESULTS}

\section{Correlation}

TABLE 1 displays descriptive statistics, correlations, and coefficient alphas for all factors extracted from the survey data. To provide a general overview of the relationships between the constructs, their correlations have been calculated and presented in TABLE 1, Cronbach's alphas are between brackets

TABLE 1

\begin{tabular}{|c|c|c|c|c|c|c|c|c|c|c|c|c|}
\hline & & $M$ & $S D$ & 1 & 2 & 3 & 4 & 5 & 6 & 7 & 8 & 9 \\
\hline 1 & $\begin{array}{l}\text { Employee } \\
\text { well-being }\end{array}$ & 4.05 & 49 & $(.79)$ & & & & & & & & \\
\hline 2 & $\begin{array}{l}\text { Transactional } \\
\text { PCB }\end{array}$ & 2.49 & .66 & $-.26 * *$ & (.67) & & & & & & & \\
\hline 3 & $\begin{array}{l}\text { Relational } \\
\text { PCB }\end{array}$ & 2.50 & .84 & $-.34 * *$ & $.26 * *$ & $(.88)$ & & & & & & \\
\hline 4 & $\begin{array}{l}\text { Quiescent } \\
\text { silence }\end{array}$ & 2.00 & .91 & $-.37 * *$ & -.10 & $.46^{* *}$ & $(.90)$ & & & & & \\
\hline 5 & $\begin{array}{l}\text { Pro-social } \\
\text { silence }\end{array}$ & 2.22 & .87 & $-.24 * *$ & .03 & $.32 * *$ & $.50 * *$ & $(.88)$ & & & & \\
\hline 6 & $\begin{array}{l}\text { Abusive } \\
\text { supervision }\end{array}$ & 1.50 & .67 & $-.37 * *$ & $.23 * *$ & $.49 * *$ & $.55^{*}$ & $.41 * *$ & $(.95)$ & & & \\
\hline 7 & Gender & .63 & .48 & -.04 & -.04 & .11 & .04 & -.01 & -.01 & & & \\
\hline 8 & Age & 39.90 & 14.75 & $.20 * *$ & .06 & -.05 & .05 & .06 & .07 & $.17 * *$ & & \\
\hline 9 & Org. tenure & 10.20 & 11.47 & $.14^{*}$ & -.04 & .04 & -.07 & -.07 & .06 & $-.23 * *$ & $.61 * *$ & \\
\hline
\end{tabular}

Note. $n=259$. Cronbach's aalpha coefficients are shown on the diagonal (in parentheses). $P C B=$ psychological contract breach. $M=$ means and $S D=$ standard deviation. Gender is coded: female $=0$, male $=1 . p<.05=*, p$ $<.01=* *$.

The correlation table shows that employee well-being and transactional psychological contract breach have a moderate negative correlation $(R=-.26)$. Furthermore, employee well-being and relational psychological contract breach also have a moderate negative correlation $(R=-.34)$. Also, employee wellbeing has a negative moderate correlation with both quiescent silence and with abusive supervision $(R=-$ .37). Next, the variable relational psychological contract breach has a highly moderate correlation with quiescent silence $(R=.46)$, a moderate correlation with pro-social silence $(R=.32)$ and a highly moderate correlation with abusive supervision $(R=.49)$. Furthermore, the variable quiescent silence has a rather high correlation with pro-social silence $(R=.50)$. The correlation between quiescent silence and abusive supervision $(R=.50)$ is also high. The variable pro-social silence is moderately correlated with abusive supervision $(R=.41)$. Lastly, abusive supervision has a high correlation with quiescent silence $(R=50)$, though the significance level is $<.05$.

\section{Regression Analyses}

This section shows the results of regression analyses in order to evaluate the effects of the control variables. 
TABLE 2

RESULTS OF HIERARCHICAL REGRESSION ANALYSIS WITH DEPENDENT VARIABLE QUIESCENT SILENCE

\begin{tabular}{|c|c|c|c|c|c|c|c|c|}
\hline & \multicolumn{2}{|c|}{ Model 1} & \multicolumn{2}{|c|}{ Model 2} & \multicolumn{2}{|c|}{ Model 3} & & \\
\hline & B-value & $t$-value & B-value & $t$-value & B-value & $t$-value & \multicolumn{2}{|c|}{ First Last } \\
\hline Gender & .07 & .54 & -.01 & -.05 & .01 & $2.13^{*}$ & & \\
\hline Age & .01 & 1.90 & .01 & 1.90 & .01 & .06 & & \\
\hline Org. tenure & -.01 & -1.87 & -.02 & $-.93 * *$ & -.01 & $-3.22 * * *$ & & \\
\hline \multicolumn{9}{|l|}{ Predictor var } \\
\hline TA PCB & & & -.01 & -1.33 & .06 & .91 & $.41 * * *$ & .00 \\
\hline Rel PCB & & & .28 & $4.38 * * *$ & .27 & $-4.40 * * *$ & $.37 * * *$ & $.04 * * *$ \\
\hline Abusive sup. & & & .61 & $7.76^{* * *}$ & .64 & $6.98 * * *$ & $.22 * * *$ & $.19 * * *$ \\
\hline \multicolumn{9}{|c|}{ Interaction terms } \\
\hline PCB_R $\times$ AS & & & & & $\begin{array}{l}-.11 \\
.23\end{array}$ & $\begin{array}{l}-1.11 \\
3,26^{* * *}\end{array}$ & $.02 * *$ & .00 \\
\hline & & & & & & & .00 & $.02 * * *$ \\
\hline$R^{2}$ & & .02 & & $.38 * * *$ & & .43 & & \\
\hline Adjusted $R^{2}$ & & .01 & & .37 & & .41 & & \\
\hline$F$-statistic & & 1.64 & & $25.36^{* * *}$ & & $26.01 * * *$ & & \\
\hline $\mathrm{DF}(\mathrm{df} 1, \mathrm{df} 2)$ & & 3,253 & & 6,250 & & 8,279 & & \\
\hline
\end{tabular}

TABLE 2 presents the results of the hierarchical regression analysis focusing on quiescent silence. The results show that the predictors added in model 2 and model 3 increased the adjusted $R^{2}$ by $37 \%$ in model 2 and $41 \%$ in model 3. In all models, the $F$-statistic appears to be significant (model 2, $F=25.36, p$ $<.001$; model $3, F=26.01, p<.001)$. In model 3 , the control variable organizational tenure $(t=-3.22, p$ $<.001)$ was significant for the relation between psychological contract breach and quiescent silence. The predictor variables in model 2 , relational psychological contract breach $(r=4.38, p<.001)$ and abusive supervision $(r=7.76, p<.001)$, were significantly and positively related to quiescent silence. Furthermore, model 3 shows that the interaction terms of relational psychological contract breach with abusive supervision was significantly positively related to quiescent silence $(r=2.63, p<.001)$. Lastly, model 3 shows that there was no significant relation between transactional psychological contract breach and quiescent silence, nor was there any interaction with abusive supervision. 
TABLE 3

RESULTS OF HIERARCHICAL REGRESSION ANALYSIS WITH DEPENDENT VARIABLE PRO-SOCIAL SILENCE

\begin{tabular}{|c|c|c|c|c|c|c|c|c|}
\hline & \multicolumn{2}{|c|}{ Model 1} & \multicolumn{2}{|c|}{ Model 2} & \multicolumn{2}{|c|}{ Model 3} & \multirow[b]{2}{*}{ First Last } & \\
\hline & B-value & $t$-value & B-value & $t$-value & B-value & $t$-value & & \\
\hline Gender & -.04 & -.38 & -.10 & -.90 & -.11 & -1.13 & & \\
\hline Age & .01 & $2.01 *$ & .01 & 1.89 & .01 & 1.71 & & \\
\hline Org. tenure & -.01 & $-2.05^{*}$ & -.01 & $-2.67 * *$ & -.01 & $-2.88 * *$ & & \\
\hline \multicolumn{9}{|l|}{ Predictor var } \\
\hline TA PCB & & & -.12 & -1.60 & .13 & 1.69 & $.24 * * *$ & .01 \\
\hline Rel. PCB & & & .19 & $2.74 * *$ & -.20 & $-3.01 * *$ & $.22 * * *$ & $.02 * *$ \\
\hline Abusive sup. & & & .44 & $5.23 * * *$ & .48 & $4.78 * * *$ & $.13 * * *$ & $.12 * * *$ \\
\hline \multicolumn{9}{|l|}{ Interaction } \\
\hline PCB_T x AS & & & & & -.12 & -1.01 & $.22 * *$ & .00 \\
\hline PCB_R $\times$ AS & & & & & .23 & $3.03 * *$ & .00 & $.03 * *$ \\
\hline$R^{2}$ & & .02 & & .21 & & .27 & & \\
\hline Adjusted $R^{2}$ & & .01 & & .19 & & .25 & & \\
\hline$F$-statistic & & 1.74 & & $11.26 * * *$ & & $12.68 * * *$ & & \\
\hline $\mathrm{DF}(\mathrm{df} 1, \mathrm{df} 2)$ & & 3,253 & & 6,250 & & 8.279 & & \\
\hline \multicolumn{9}{|c|}{$\begin{array}{l}\text { Note. } n=259 . P C B \_T=\text { psychological contract breach transactional. } P C B \_R=\text { psychological contract breach } \\
\text { relational. } A S=\text { abusive supervision. } p<.05=*, p<.01=* *, p<.001=* * *\end{array}$} \\
\hline \multicolumn{9}{|c|}{$\begin{array}{l}\text { The predictor variables in model } 2 \text {, relational psychological contract breach }(r=2.74, p<.01) \text { and } \\
\text { abusive supervision }(r=5.23, p<.001) \text {, were significant and positively related to pro-social silence. } \\
\text { Furthermore, the direct relation between relational psychological contract breach and pro-social silence } \\
\text { was negatively related, meaning that when a relational based breach is perceived, someone is less } \\
\text { willingly to remain silent. However, the interaction terms of abusive supervision and relational } \\
\text { psychological contract breach were significantly positive. This indicates that whenever abusive } \\
\text { supervision arises, employees' intent to be less willingly to remain silent increases. In model } 3 \text {, the } \\
\text { control variable, organizational tenure }(t=-3.22, p<.001) \text { was found to be a significant control variable } \\
\text { for the relation between psychological contract breach and pro-social silence. Model } 3 \text { shows that } \\
\text { transactional psychological contract breach as an independent variable had no significant relation with } \\
\text { pro-social silence as a dependent variable, nor was there a significant interaction with abusive } \\
\text { supervision. When considering the last column in TABLE } 3 \text {, it is evident that when transactional } \\
\text { psychological contract breach is added first, an additional } 24 \%(p<.001) \text { of explained variance indicates } \\
\text { that this independent variable significantly adds to the explained variance. }\end{array}$} \\
\hline
\end{tabular}




\section{RESULT OF HIERARCHICAL REGRESSION ANALYSIS WITH DEPENDENT VARIABLE EMPLOYEE WELL-BEING}

\begin{tabular}{|c|c|c|c|c|c|c|}
\hline & \multicolumn{2}{|c|}{ Model 1} & \multicolumn{2}{|c|}{ Model 2} & \multirow{2}{*}{\multicolumn{2}{|c|}{ First Last }} \\
\hline & B-value & $t$-value & B-value & $t$-value & & \\
\hline Gender & .00 & .03 & .02 & $3.31 * * *$ & & \\
\hline Age & .01 & $2.39 *$ & .01 & -.21 & & \\
\hline Org. tenure & .00 & .36 & -.00 & & & \\
\hline \multicolumn{7}{|l|}{ Predictor variables } \\
\hline TA PCB & & & -.13 & $-3.01 * *$ & $.06 * * *$ & $.03 * *$ \\
\hline Rel. PCB & & & -.10 & $-2.61 * *$ & $.12 * * *$ & $.02 * *$ \\
\hline Quiescent silence & & & -.14 & $-.3 .81 * * *$ & $.15^{* * *}$ & $.04 * * *$ \\
\hline Pro-social silence & & & -.04 & -.97 & $.06 * * *$ & .00 \\
\hline & & .42 & & .26 & & \\
\hline Adjusted $R^{2}$ & & .03 & & .24 & & \\
\hline$F$-statistic & & $3.68 *$ & & $12.30 * * *$ & & \\
\hline DF (df1, df2) & & 3,253 & & 7,249 & & \\
\hline
\end{tabular}

Note. $n=259, p<.05=*, p<.01=* *, p<.001=* * *$

TABLE 4 presents the hierarchical regression analysis, which shows the direct relation of the dependent and independent variables. The results show that the predictors, added in model 2, increased the adjusted $R^{2}$ from .03 to .24 . Moreover, in model $1(t=3.68, p<.05)$ and model $2(t=12.30, p<.001)$, the $F$-statistic appears to increase significantly, when adding the predictor variables. In model 2 , gender was found to be a significant positive control variable $(t=3.31, p<.001)$. In model 2 it appears that both transactional psychological contract breach $(t=-3.01,<.01)$ and relational psychological contract breach $(r=-2.61, p<.01)$, were negatively related to employee well-being. Moreover, the direct relationship between quiescent silence and employee well-being was significantly negative $(t=-3.81, p<.001)$. There was no significant relation found between pro-social silence and employee well-being. When considering the last column in TABLE 4, it is evident that when transactional psychological contract breach is added first, an additional $6 \%(p<.001)$ of explained variance indicates that this independent variable significantly adds to the explained variance. This is the same for relational psychological contract breach $\left(\Delta R^{2}=12 \%, p<.001\right)$, quiescent silence $\left(\Delta R^{2}=15 \%, p<.001\right)$ and pro-social silence $\left(\Delta R^{2}=6 \%, p\right.$ $<.001)$.

\section{DISCUSSION AND CONCLUSION}

The present study aimed to examine the relationship between psychological contract breach and employee well-being, and to examine whether silence indirectly mediates this relationship, with an influence of abusive supervision. The results of the analyses showed that both the transactional psychological contract breach and the relational psychological contract breach were negatively related to employee well-being. Hypothesis 1 and hypothesis 2 are therefore supported, as there is a significant negative relationship between the independent and the dependent variable. It was hypothesized that transactional and relational psychological contract breaches would be positively related to quiescent silence as well as to pro-social silence. The results showed that only relational psychological contract breach had a significant positive relationship with quiescent silence and pro-social silence. Transactional psychological contract breach was shown to have no significant relationship with quiescent silence, nor 
with pro-social silence. It was hypnotized that both quiescent silence and pro-social silence should mediate the relationship between transactional and relational psychological contract breach and employee well-being. However, the results indicate that only quiescent silence mediates the relationship between relational psychological contract breach and employee well-being. Thus, the relation between transactional psychological contract breach and employee well-being is not significantly mediated by any form of silence, nor is pro-social silence mediating the relation between relational contract breach and employee well-being. Based on existing literature, it was expected that both quiescent silence as well as pro-social silence would mediate the relationship between transactional and relational psychological contract breach and employee well-being. However, not all relationships were found to be significant. It was hypothesized that abusive supervision would moderate the positive relationship between psychological contract breach and silence. The results of this study show that abusive supervision indeed strengthens the relationship between relational psychological contract breach and silence.

\section{Main Findings and Theoretical Implications}

The main aim of this study was to examine the direct and indirect relationship between the included constructs by examining psychological contract breach as it is perceived by employees, the comprehensiveness of silence and the moderating effect that abusive supervision has on the relationship between psychological contract breach, silence, and indirectly on employee well-being. This study showed that transactional and relational psychological contract breach were statistically significantly negatively related to employee well-being, which was in line with the hypothesis and with other studies (Schaufeli \& Enzmann, 1998; Conway \& Briner, 2002; Zhao et al., 2007; Bal et al., 2010; Robbinson, Ford \& Terick; 2012 (Reimann \& Guzy, 2016)). It was examined to what extent psychological contract breach is related to silence. The academic literature used in this study suggested most employees often decide to remain silent in order to keep their job. However, psychological contract breaches are interrelated to job commitment and turnover intention (Cooper-Hakim \& Viswesvaran, 2005). Robinson and Rousseau (1994) mention that transactional-based psychological contract breach lead to a increase in the willingness to remain silent, as the perception of a fair economic exchange is damaged. However, no significant relation between the constructs was found. It could be argued that this is due to the foundations of the transactional psychological contracts, as these types of contracts are often fixed and less prone to misconceptions (Bingham, 2015). It was examined to what extent silence is related to employee wellbeing. In this study, there was only a significant relationship found between quiescent silence and employee well-being, and no such significant relationship between pro-social silence and employee wellbeing. Pro-social silence was not found to have any significant relationship with employee well-being. It could be argued that this is due to the fact that pro-social silence is focused on the benefit of others and on being considerate of one's surroundings. Another subquestion concerned the mediating effect of silence on the relationship between psychological contract breach and employee well-being. The academic literature suggests that both sub-dimensions of silence mediate the relationship between these two constructs (Brinsfield, 2009; Gross \& Levenson, 1997; Knoll \& van Dick, 2013; Milliken et al., 2003; Morrison \& Milliken, 2000; Richard \& Gross, 1999; Van Dyne et al., 2003). Based on the results in this study, it can be said that only the relationship between relational psychological contract breach and employee well-being is mediated by quiescent silence. The results showed there was no significant interaction between the transactional psychological contract breach and silence. However, this study did find support for the moderating effect of abusive supervision on the relationship between relational psychological contract breach and silence. In regard to the indirect influence of the moderator on employee well-being, this study found that abusive supervision significantly affected employee wellbeing.

\section{Limitations and Future Research}

The choice of research design might cause debate due to the alterations of the formulations of the questions of the survey used in this study. Not only were the academic literature and measurements originally in English, also the Likert-scale scoring had to be altered due to formulation and translation 
inefficiencies. These inefficiencies came to light during the explanatory factor analysis, where some questions needed to be taken out, as the answers to these questions were inconsistent with other answers, resulting in a cross-loading with other factors. These cross-loadings could have occurred due to the translation from English to Dutch (Douglas \& Craig, 2007). Moreover, this study has been conducted in a relatively short period of time, which means it was a cross-sectional investigation. According to Rousseau (1989), the perception of a psychological contract breach can change over time, as it is possible for an individual to change perspectives. Furthermore, the reasons for turning silent are not developed within a short timeframe. Additionally, turning silent for the benefit for people around you, will only occur is there is a relationship with these people. Therefore, a future study with a more longitudinal research design is preferred.

\section{Practical Implications and Conclusion}

For practical recommendations, this study found support for the relationship between relational psychological contract breach and employee well-being. As employees' health and well-being should be a priority for organizations, a greater focus should be put on accumulated knowledge and skills that make a workforce productive (Kodden \& Groenveld, 2019; Schaufeli \& Bakker, 2001; Zheng et al., 2015). Employees who are at ease in their working situation will be more productive, energetic and valuable for the organization (Schaufeli, Bakker, \& Van Rhenen, 2009). Furthermore, a psychological contract with a focus on relations within the organization will be established in the early stage of employment and will become the base on which employees connect themselves with the organization (Rousseau, 1989). In order to establish and maintain a positive and striving relationship with their employees, managers should acknowledge the obligations they include in any psychological contract. Simply put, managers should stay on top of their promises towards their employees and be aware when promises are not fulfilled. Open and forthright communication is essential to grasp the understanding of a relational psychological contract and to recognize a breach.

\section{REFERENCES}

Abid, S., \& Abid., H. (2017). Abusive supervision and turnover intention among female healthcare professionals in Pakistani hospitals. International Journal of Advanced Research, 5(11), 470-479.

Adebayo, S. O., \& Ogunsina, S. O. (2011). Influence of supervisory behavior and job stress on job satisfaction and turnover intention of police personnel in Ekiti State. Journal of Management and Strategy, 2(3), 13-20.

Armstrong, M. (2006). A handbook of human resource management practice (tenth edn.). London: Kogan Page.

Arthur, M. B. \& Rousseau, D. M. (1996). The boundaryless career as a new employment principle. The Boundaryless career (pp. 3-20). Oxford: Oxford University Press, 1(0).

Aryee, S., Chen, Z. X., Sun, L. Y., \& Debrah, Y. A. (2007). Antecedents and outcomes of abusive supervision: Test of a trickle-down model. Journal of Applied Psychology, 92(1), 191-201.

Aryee, S., Walumbwa, F. O., Zhou, Q., \& Hartnell, C. A. (2012). Transformational leadership, innovative behavior, and task performance: Test of mediation and moderation processes. Human Performance, 25(1), 1-25.

Bagheri, G., Zarei, R., \& Aeen, M. (2012). Organizational silence (basic concepts and its development factors). Ideal Type of Management, 1(1), 49-50.

Bakker, A., \& Oerlemans, W. G. M. (2011). Subjective well-being in organizations. Handbook of positive organizational scholarship. Oxford: Oxford University Press.

Bal, P. M., De Cooman, R., \& Mol, S. T. (2013). Dynamics of psychological contracts with work engagement and turnover intention: The influence of organizational tenure. European Journal of Work and Organizational Psychology, 22(1), 107-122. 
Beheshtifar, M., Borhani, H., \& Moghadam, M. N. (2012). Destructive role of employee silence in organizational success. International Journal of Academic Research in Business and Social Sciences, 2(11), 275-282.

Berkman, P. L. (1971a). Life stress and psychological wellbeing: A replication of Langer's analysis in the midtown Manhattan study. Journal of Health and Social Behavior, 12(0), 35-45.

Berkman, P. L. (1971b). Measurement of mental health in a general population survey. American Journal of Epidemiology, 94(2), 105-111.

Bingham, J. (2005). Multiple obligations: Distinguishing the dimensionality and conforming the role of ideology within the psychological contract framework.

Blau, P. M. (1964). Exchange and power in social life. New York: John Wiley \& Sons.

Blomme, R. J., Kodden, B., \& Beasley-Suffolk, A. (2015). Leadership theories and the concept of work engagement: Creating a conceptual framework for management implications and research. Journal of Management and Organization, 21(2), 125-144.

Blomme, R. J., \& Kodden, S. F. G. P. (2014). Engagement as a new concept in the hospitality industry. The role of management in increasing engagement among hospitality workers. In I. S. Pantelidis (Ed.), Routledge handbook of hospitality management (pp. 67-76). Oxon, UK: Routledge.

Bolino, M. C., \& Turnley, W. H. (2003). Going the extra mile: Cultivating and managing employee citizenship behavior. Academy of Management Perspectives, 17(3), 60-71.

Bradburn, N. M., \& Caplovitz, D. (1965). Reports on happiness. Chicago: Aldine.

Brinsfield, C. T. (2009). Employee silence: Investigation of dimensionality, development of measures, and examination of related factors. (Dissertation). Retrived from https://etd.ohiolink.edu/!etd.send_file?accession=osu1236294604\&disposition=inline

Brinsfield, C. T. (2013). Employee silence motives: Investigation of dimensionality and development of measures. Journal of Organizational Behavior, 34(5), 671-697.

Brinsfield, C. T., Edwards, M. S., \& Greenberg, J. (2009). Voice and silence in organizations: Historical review and current conceptualizations. In J. Greenberg \& M. Edwards (Eds.), Voice and silence in organizations (Vol. 1, pp. 1-33).

Burton, J., \& Hoobler, J. (2006). Subordinate self-esteem and abusive supervision. Journal of Managerial Issues, 18(0), 340-355.

Buunk, B. P., \& Schaufeli, W. B. (1999). Reciprocity in interpersonal relationships: An evolutionary perspective on its importance for health and well-being. European Review of Social Psychology, 10(1), 259-291.

Chambel, M. J., \& Oliveira-Cruz, F. (2010). Breach of psychological contract and the development of burnout and engagement: A longitudinal study among soldiers on a peacekeeping mission. Military Psychology, 22(2), 110-127.

Conway, N., \& Briner, R. B. (2002). A daily diary study of affective responses to psychological contract breach and exceeded promises. Journal of Organizational Behavior, 23(3), 287-302.

Conway, N., \& Briner, R. B. (2005). Understanding psychological contracts at work: A critical evaluation of theory and research. NY: Oxford University Press.

Conway, N., \& Coyle-Shapiro, J. A. -M. (2006). Reciprocity and psychological contracts: Employee performance and contract fulfillment. Academy of Management Proceedings. Paper presented at the annual meeting of the Academy of Management, Atlanta, United States, (1), Q1-Q6.

Cooper-Hakim, A., \& Viswesvaran, C. (2005). The construct of work commitment: Testing an integrative framework. Psychological Bulletin, 131(2), 241-259.

Cortina, L. M., \& Magley, V. J. (2003). Raising voice, risking retaliation: Events following interpersonal mistreatment in the workplace. Journal of Occupational Health Psychology, 8(4), 247-265.

Costa, S., \& Neves, P. (2017). It is your fault! How blame attributions of breach predict employees' reactions. Journal of Managerial Psychology, 32(7), 470-483.

Coyle-Shapiro, J. A. M. (2002). A psychological contract perspective on organizational citizenship behavior. Journal of Organizational Behavior, 23(8), 927-946. 
Coyle-Shapiro, J., \& Kessler, I. (2000). Consequences of the psychological contract for the employment relationship: A large-scale survey. Journal of Management Studies, 37(7), 903-930.

Croteau, A., Dyer, L., \& Miguel, M. (2010). Employee reactions to paper and electronic surveys: An experimental comparison. IEEE Transactions on Professional Communication, 53(3), 249-259.

Dabos, G. E., \& Rousseau, D. M. (2004). Mutuality and reciprocity in the psychological contracts of employees and employers. Journal of Applied Psychology, 89(1), 52-72.

Daniels, K. (2000). Measures of five aspects of affective well-being at work. Human Relations, 53(2), 275-294.

Danna, K., \& Griffin, R. W. (1999). Health and well-being in the workplace: A review and synthesis of the literature. Journal of Management, 25(3), 357-384.

Deniz, N., Noyan, A., \& Ertosun, Ö. G. (2013). The relationship between employee silence and organizational commitment in a private healthcare company. Procedia - Social and Behavioral Sciences, 99(0), 691-700.

Detert, J. R., \& Burris, E. R. (2007). Leadership behavior and employee voice: Is the door really open? Academy of Management Journal, 50(4), 869-884.

Detert, J. R., Burris, E. R., \& Harrison, D. A. (2010). Debunking four myths about employee silence. Harvard Business Review, 88(6), 26.

Detert, J. R., \& Edmondson, A. C. (2011). Implicit voice theories: Taken-for-granted rules of selfcensorship at work. Academy of Management Journal, 54(3), 461-488.

Diener, E., Sandvik, E., \& Pavot, W. (1991). Happiness is the frequency, not the intensity, of positive versus negative affect. In F. Strack, M. Argyle \& N. Schwarz (Eds.), Subjective well-being: An interdisciplinary perspective. New York: Pergamon Press.

Douglas, S. P., \& Craig, C. S. (2007). Collaborative and iterative translation: An alternative approach to back translation. Journal of International Marketing, 15(1), 30-43.

Edmonson, A. C. (1999). Psychological safety and learning behavior in work teams. Administrative Science Quarterly, 44(0), 350-383.

Goodrich, K. (2014). The gender gap: Brain-processing differences between the sexes shape attitudes about online advertising. Journal of Advertising Research, 54(1), 32-43.

Graham, J. W. (1995). Leadership, moral development, and citizenship behavior. Business Ethics Quarterly, 5(1), 43-54.

Grant, A. M., Christianson, M. K., \& Price, R. H. (2007). Happiness, Health, or Relationships? Managerial practices and employee well-being tradeoffs. Academy of Management Perspectives, 21(3), 51-63.

Hartwell, T. D., Steele, P., French, M. T., Potter, F. J., Rodman, N. F., \& Zarkin, G. A. (1996). Aiding troubled employees: The prevalence, cost, and characteristics of employee assistance programs in the United States. American Journal of Public Health, 86(6), 804-808.

Heilman, M. E., \& Chen, J. J. (2005). Same behaviour, different consequences: Reactions to men's and women's altruistic citizenship behaviour. Journal of Applied Psychology, 90(3), 431-441.

Jain, A. K. (2015). An interpersonal perspective to study silence in Indian organizations. Personnel Review, 44(6), 1010-1036.

Johnson, N. J., \& Klee, T. (2007). Passive-aggressive behavior and leadership styles in organizations. Journal of Leadership \& Organizational Studies, 14(2), 130-142.

Knoll, M., \& van Dick, R. (2013). Do I hear the whistle. . .? A first attempt to measure four forms of employee silence and their correlates. Journal of Business Ethics, 113(2), 349-362.

Kodden, B., \& Groenveld, B. (2019). The mediating effect of work engagement on the relationship between person-organization fit and knowledge sharing. Journal of Applied Business and Economics, 21(8).

Kodden, B., \& van Ingen, R. (2019). Knowledge productivity in the 2020s: Time for a new E/RA A research study on the impact of organizational design and employee engagement on the knowledge productivity of service firms. Journal of Applied Business and Economics, 21(4).

Kodden, S. F. G. P. (2014). Be a HERO. Bernard Daniel Press. 
Kodden, S. F. G. P., \& Hupkes, L. (2019). Organizational environment, personal resources and work engagement as predictors of coaching performance. Journal of Management Policy and Practice, 20(3).

Kodden, S. F. G. P., \& Roelofs, J. (2019). Psychological contract as a mediator of the leadership- turn over intentions relationship. Journal of Organizational Psychology, 19(2).

Korsgaard, M. A., Meglino, B. M., \& Lester, S. W. (1997). Beyond helping: Do other-oriented values have broader implications in organizations? Journal of Applied Psychology, 82(1), 160-177.

Langner, T. S., \& Michael, S. T. (1963). Life stress and mental health. Glencoe: Free Press.

LePine, J. A., Erez, A., \& Johnson, D. E. (2002). The nature and dimensionality of organizational citizenship behavior: A critical review and a meta-analysis. Journal of Applied Psychology, 87(1), 52-65.

MacNeil, I. R. (1985). Relational contract: What we do and do not know. Wisconsin Law Review, 4(0), 483-525.

Bal, P. M., Chiaburu, D. S., \& Jansen, P. G. W. (2010). Psychological contract breach and work performance: Is social exchange a buffer or an intensifier? Journal of Managerial Psychology, 25(3), 252-273.

McLean Parks, J., Kidder, D. L., \& Gallagher, D. G. (1998). Fitting square pegs into round holes: Mapping the domain of contingent work arrangements onto the psychological contract. Journal of Organizational Behavior, 19(1), 697-730.

Morrison, E. W. (2014). Employee voice and silence. Annual Review of Organizational Psychology and Organizational Behavior, 1(1), 173-197.

Morrison, E. W., \& Milliken, F. J. (2000). Organizational silence: A barrier to change and development in a pluralistic world. Academy of Management Review, 25(4), 706-725.

Morrison, E. W., \& Robinson, S. L. (1997). When employees feel betrayed: A model of how psychological contract violation develops. Academy of Management Review, 22(1), 226-256.

Neubert, M. J., \& Taggar, S. (2004). Pathways to informal leadership: The moderating role of gender on the relationship of individual differences and team member network centrality to informal leadership emergence. The Leadership Quarterly, 15(2), 175-194.

Nisar, A., Q., \& Liaqat, I. (2017). The crucial role of psychological contracts towards organizational behaviors: Descriptive study in banking sector. International Journal for Research in Social Science and Humanities, 3(6), 1-12.

Nussbaum, M. C. (2001). Symposium on Amartya Sen's philosophy: 5 adaptive preferences and women's options. Economics and Philosophy, 17(0), 67-88.

Osborne, J. W. (2014). Best practices in exploratory factor analysis. Scotts Valley, CA: CreateSpace Independent Publishing.

Page, K. M., \& Vella-Brodrick, D. A. (2009). The "what," "why" and "how" of employee well-being: A new model. Social Indicators Research, 90(3), 441-458.

Patrick, H. A. (2008). Psychological contract and employment relationship. University. Journal of Organizational Behavior, 7(0), 4-21.

Perlow, L. A., \& Repenning, N. P. (2009). Review. The dynamics of silencing conflict. Research in Organizational Behavior, 29(0), 195-223.

Perlow, L. A., \& Williams, S. (2003). Is silence killing your company? Harvard Business Review, 81(5), $52-8,128$,

Pinder, C. C., \& Harlos, K. P. (2001). Employee silence: Quiescence and acquiescence as responses to perceived injustice. Research in Personnel and Human Resources Management, 20, 331-369.

Qian, J., Song, B. \& Wang, B. (2017). Abusvie Supervision and Job Dissatisfaction: The Moderating Effects of Feedback Avoidance and Critical Thinking. Frontiers in Psychology.

Reimann, M., \& Guzy, J. (2016). Psychological contract breach and employee health: The relevance of unmet obligations for mental and physical health. Journal of Work and Organizational Psychology, 1(0), 1-11 
Roberts, K. H., \& O'Reilly, C. A. (1974). Failures in upward communication in organizations: Three possible culprits. Academy of Management Journal, 17(0), 205-215

Robinson, S. L., \& Rousseau, D. M. (1994). Violating the psychological contract: Not the exception but the norm. Journal of Organizational Behavior, 15(3), 245-259.

Robbins, J. M., Ford, M. T., \& Tetrick, L. E. (2012). Perceived unfairness and employee health: A metaanalytic integration. Journal of Applied Psychology, 97(2), 235-272.

Robinson, S. L., \& Wolfe Morrison, E. W. (2000). The development of psychological contract breach and violation: A longitudinal study. Journal of Organizational Behavior, 21(5), 525-546.

Rosen, S., \& Tesser, A. (1970). On reluctance to communicate undesirable information: The MUM effect. Sociometry, 33(3), 253-263.

Rousseau, D. M. (1989). Psychological and implied contracts in organizations. Employee Responsibilities and Rights Journal, 2(2), 121-139.

Rousseau, D. M. (1990). New hire perceptions of their own and their employer's obligations: A study of psychological contracts. Journal of Organizational Behavior, 11(5), 389-400.

Rousseau, D. M. (1995). Psychological contracts in organizations: Understanding written and unwritten agreements. Thousand Oaks, CA: SAGE Publications.

Russell, J. A. (1980). A circumplex model of affect. Journal of Personality and Social Psychology, 39(6), 1161-1178.

Ryan, R. M., \& Deci, E. L. (2001). On happiness and human potentials: A review of research on hedonic and eudaimonic well- being. Annual Review of Psychology, 52(1), 141-166.

Ryff, C. D., \& Keyes, C. L. M. (1995). The structure of psychological well-being revisited. Journal of Personality and Social Psychology, 69(4), 719-727.

Savickas, M. L. (2011). New questions for vocational psychology: Premises, paradigms, and practices. Journal of Career Assessment, 19(3), 251-258.

Schaufeli, W. B., \& Bakker, A. B. (2001). Werk en welbevinden: Naar een positieve benadering in de Arbeids- en Gezondheidspsychologie. Gedrag en Organisatie, 14, 229-253.

Schaufeli, W. B., Bakker, A. B., \& Van Rhenen, W. (2009). How changes in job demands and resources predict burnout, work engagement, and sickness absenteeism. Journal of Organizational Behavior, 30(7), 893-917.

Schaufeli, W. B., \& Enzmann, D. (1998). The burnout companion to study and practice: A critical analysis. London/Philadelphia, PA: Taylor \& Francis.

Shore, L. M., \& Coyle-Shapiro, J. A. M. (2003). New developments in the employee- organization relationship. Journal of Organizational Behavior, 24(5), 443-450.

Siegrist, J. (1996). Adverse health effects of high-effort/low-reward conditions. Journal of Occupational Health Psychology, 1(1), 27-41.

Singer, B. (1996). Physiological well-being: Meaning, measurement and implications for psychotherapy research. Psychotherapy and Psychosomatics, 65(0), 14-23.

Spreitzer, G., \& Porath, C. (2012). Creating sustainable performance. Harvard Business Review, 90(1-2), 92-9, 152.

Suazo, M. M., Martínez, P. G., \& Sandoval, R. (2009). Creating psycho, logical and legal contracts through human resource practices: A signaling theory perspective. Human Resource Management Review, 19(2), 154-166.

Taneva, S. K., Arnold, J., \& Nicolson, R. (2016, October). The experience of being an older worker in an organization: A qualitative analysis. Work, Aging and Retirement, 2(4), 396-414.

Tepper, B. J., Duffy, M. K., Henle, C. A., \& Lambert, L. S. (2006). Procedural injustice, victim precipitation, and abusive supervision. Personnel Psychology, 59(1), 101-123.

Tepper, B. J., Moss, S., Lockhart, D., \& Carr, J. (2007). Abusive supervision, upward maintenance communication, and subordinates' psychological distress. Academy of Management Journal, $50(0), 1169-1180$

Tepper, J. (2000). Consequences of abusive supervision. Academy of Management Journal, 43(2), 178190

52 Journal of Applied Business and Economics Vol. 22(2) 2020 
Topa Cantisano, G., Morales Domínguez, J. F., \& Depolo, M. (2008). Psychological contract breach and outcomes: Combining meta-analysis and structural equation models. Psicothema, 20(3), 487-496.

Turnley, W. H., \& Feldman, D. C. (1999a). A discrepancy model of psychological contract violations. Human Resource Management Review, 9(3), 367-386.

Turnley, W. H., \& Feldman, D. C. (1999b). The impact of psychological contract violations on exit, voice, loyalty, and neglect. Human Relations, 52(7), 895-922.

Ulrich, D. (1997). Human resource champions. Boston. MA: Harvard Business School.

Vakola, M., \& Bouradas, D. (2005). Antecedents and consequences of organizational silence: An empirical investigation. Employee Relations, 27(5), 441-458.

Van Dyne, L., Ang, S., \& Botero, I. C. (2003). Conceptualizing employee silence and employee voice as multidimensional constructs. Journal of Management Studies, 40(0), 1359-1392.

Wang, Y., \& Hsieh, H. (2014). Employees' reactions to psychological contract breach: A moderated mediation analysis. Journal of Vocational Behavior, 85(1), 57-66.

Warr, P. (1987). Work, unemployment, and mental health. Oxford: Clarendon Press.

Wei, F., \& Si, S. (2013). Psychological contract breach, negative reciprocity and abusive supervision: The mediated effect of organizational identification. Management and Organization Review, 9(3), $541-561$

Weng, Q. X., \& McElroy, J. C. (2010). Vocational self-concept crystallization as a mediator of the relationship between career self-management and job decision effectiveness. Journal of Vocational Behavior, 76(2), 234-243.

Wright, T. A., \& Cropanzano, R. (2000). Psychological well-being and job satisfaction as predictors of job performance. Journal of Occupational Health Psychology, 5(1), 84-94.

Yadav, P., \& Punia, B. K. (2013). Organizational citizenship behavior: A review of antecedents, correlates, outcomes and future research directions. IJHPD, 2(2), 1-19.

Xu, A. J., Loi, R., \& Lam, L. W. (2015). The bad boss takes it all: How abusive supervision and leadermember exchange interacts to influence employee silence. The Leadership Quarterly, 26(5), $763-$ 774.

Zellars, K. L., Tepper, B. J., \& Duffy, M. K. (2002). Abusive Supervision and Subordinates' organizational citizenship behavior. Journal of Applied Psychology, 87(6), 1068-1076.

Zhao, H., Wayne, S. J., Glibkowski, B. C., \& Bravo, J. (2007). The impact of psychological contract breach on work-related outcomes: A meta-analysis. Personnel Psychology, 60(3), 647-680.

Zheng, X., Zhu, W., Zhao, H., \& Zhang, C. (2015). Employee well-being in organizations: Theoretical model, scale development, and cross-cultural validation. Journal of Organizational Behavior, 36(5), 621-644. 